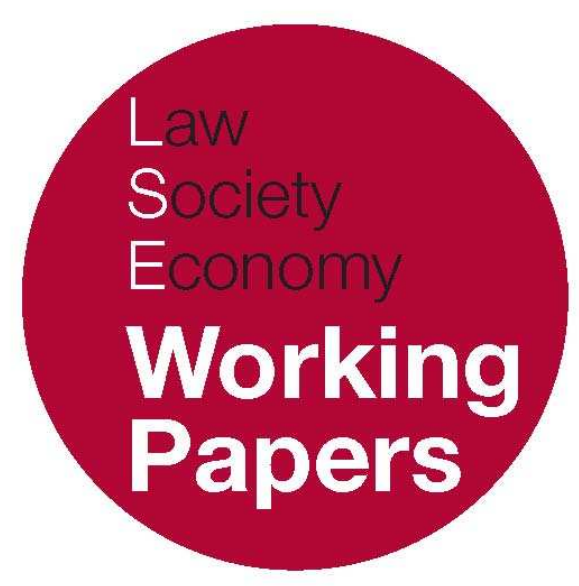

\title{
Employment Contracts for Teachers as Professional Employees
}

\author{
David Mangan \\ LSE Law, Society and Economy Working Papers 21/2009 \\ London School of Economics and Political Science \\ Law Department
}

\begin{abstract}
This paper can be downloaded without charge from LSE Law, Society and Economy Working Papers at: www.lse.ac.uk/collections/law/wps/wps.htm and the Social Sciences Research Network electronic library at: http://ssrn.com/abstract=1491613.

(C) David Mangan. Users may download and/or print one copy to facilitate their private study or for non-commercial research. Users may not engage in further distribution of this material or use it for any profit-making activities or any other form of commercial gain.
\end{abstract}




\title{
Employment Contracts for Teachers as Professional Employees
}

\author{
David Mangan *
}

\begin{abstract}
In England and Canada there is a 'professional' nuance to teachers' employment. Jurisprudence in both countries suggests a deliberate expansion of what reasonable expectations education employers have of their teacher employees. Teachers' claim to professional status forms the basis for this expansion of teachers' duties. The function of this long-held interpretation constitutes a further step in the contractualisation of teachers' work. A hallmark of reforms dating back to the 1970s has been the increasing prescription of teachers work, a point which remains at odds with the claimed professional status. The age of the relevant cases hints that contractual flexibility has been a tool during times of reform. The result is that teachers' employment contracts are understood as professional-level contracts, which means (to the courts) that not all duties must be spelled out in the contract. In fact, professional-level contracts cannot possibly include such an itemisation. Teachers are left with a series of lost decisions which reinforce not only their professional status (though in an unintended manner), but also unequivocally identify them as employees who are expected to follow all reasonable expectations of their education employers.
\end{abstract}

\section{INTRODUCTION}

Both England and Canada have lived through a seemingly longstanding tradition of public sector reform - an advantageous foundation for instructive comparison. Consecutive (though ideologically different) governments in both jurisdictions

${ }^{*}$ LSE Fellow, Law Department, London School of Economics and Political Science. My gratitude to Paul Davies, Tonia Novitz, Bob Simpson, and Phil Syrpis for comments on an earlier draft. 
have relied upon the employment contract as the chief means of regulating change in education. Academically, this is intriguing. Practically, it is limiting. The employment contract is such a force that it can constitute the means of ordering reform as well as the interactions between employer and employee Improvement in the education system has only moved in a singular direction from government to teachers. This paradigm of the single model employment contract has proven to be tremendously difficult to renovate; ${ }^{1}$ sadly so, as there is potential for public benefit in a better artifice for change management. What remains is a system in which reforms have carried contractual implications for teachers based on their status as employed professionals. The working proposition is that professional expectations form the basis for an expansion of expectations which education employers (in maintained schools) can have of their employee teachers. ${ }^{2}$

There has been a symmetry of movement in both jurisdictions which is most instructive: a Conservative government was elected on a broad reform agenda; it centralised control of education and reconfigured management of the system, especially with regards to the role of teachers; teachers (and their unions) were castigated by government for delaying improvements, and teachers retorted with fervent opposition to these changes; after years of conflict with teachers, a new, less confrontational government was elected (an ostensibly more liberal government being Labour in England and Liberal in Ontario); and a more cooperative era emerged, but also one in which teachers' unions appeared unsure of their paths. ${ }^{3}$ The patterns started out separated by about 15 years, but recently there has been temporal alignment.

Regarding the discipline of labour law, when discussing professionals as employees, an amorphous version of time has always constituted the norm as opposed to the view held by traditional labour law. ${ }^{4}$ Instead of prescribed hours or shift work, professionals' working time has only been governed by the underlying ethos of 'getting the job done' (length of time forming a basis for other items such as billing). Education employers have long taken advantage of this area simply because contract terms tend to be incompletely specified and professional

\footnotetext{
${ }^{1}$ For example, the NASUW'T note in their members survey after the National Agreement with education stakeholders: 'Teachers' responses to this survey suggest that schools have recognised the importance of having in place the necessary contractual provisions for teachers' (NASUWT, Implementing the National Agreement 'Raising Standards and Tackling Workload' (NASUWT Report, February 2006), 19.

2 The working belief is that this form of contract (though not the personal employment contract to which the comments were directed) enters into the discussion Freedland has recently expanded upon pertaining to the tightly constrained tradition of contracts of employment (M. Freedland, 'From the Contract of Employment to the Personal Work Nexus' (2006) 35 Industrial Law Journal 1, 25).

${ }^{3}$ What is meant by teachers' unions in both jurisdictions becoming unsure at the same time is that with the 'preferred' government in power, the unions are loathe to take action leading to a new government, and yet the present administration is not always doing what the unions wish.

${ }^{4}$ Now, there are many who have pointed to a growing use of time in many different ways within the umbrella of employment law. For example, 'time has now become diffuse and fragmented, and therefore reluctant to be captured by a labour law that regulates employment in the traditional dimension of time' (A. Goldin, 'The Subjective Weakening of Labour Law' in G. Davidov and B. Langille (eds), Frontiers and Boundaries of Labour Law (Oxford: Hart Publishing, 2006) 109, 114).
} 
contracts that much more so. ${ }^{5}$ With the increase of employed professionals, the classical ideal of autonomy, which has often been used to mark the distinction between a profession and an occupation, has been slowly undermined. There is greater prescription of the work professionals perform (instead of an option to choose their work). At one time antithetical to the status of professions, today more doctors and lawyers (together forming the classical ideal of professions) work as employees; that is, they are employed in situations where their work duties are prescribed. The experience of teachers assists in articulating this change.

Teachers appear to have always been in a position of subordination to their employers in comparison with other professional groupings. While teachers may have professional obligations, workplace expectations have long been expanding. While teachers' work has been increasingly prescribed since the early 1980s, their work obligations have exceeded the explicit terms of the employment contract because of their status as professionals. Work has become a complicated mixture of what is identified and what is expected, but not identified. These added duties have been categorised as being part of the professional work expected of teachers. With potential for application to other professionals, the essence of this concept consists of an explanation for the expansion of legitimate expectations from professional employees.

\section{TEACHERS AS EMPLOYEES}

In the midst of the reforms of state-funded education in England and Wales of the 1980s, teachers initiated an ardent campaign of industrial action. The court in Sim v Rotherham Metropolitan Borough Council adjudicated one of these industrial actions; 6 a work-to-rule campaign in which members of the National Union of Teachers withdrew services such as coverage of a class for an absent colleague. Teachers contended that such coverage was a voluntary act. The Council disagreed, arguing this was part of teachers' employment contracts. Ruling in favour of the Council, Mister Justice Scott relied on contract principles as applied to professionals:

The contracts are in general silent as to the extent of the teachers' obligations as teachers...This feature of the teachers' contracts does not seem to me a matter of surprise. A contract for the employment of a professional in a professional capacity would not normally be expected to detail the professional obligations expected of the employee under the employment contract. It would surprise me if a contract of employment of a solicitor by a solicitors' firm were to attempt to spell out his professional obligations owed under the contract. Nor would I expect the contract by which a doctor was

\footnotetext{
${ }^{5}$ M.R. Freedland, The Personal Employment Contract (Oxford: Oxford University Press, 2006), 126.

${ }^{6}$ [1986] I.C.R. 897 (hereinafter 'Sim').
} 
employed by a hospital or by a health authority to spell out the professional obligations of the doctor. The solicitor would be employed as a solicitor; the doctor as a doctor. The plaintiffs are employed as teachers. ${ }^{7}$

As a result of their professional status, teachers' employment contracts contained a broad range of roles and duties, both explicit and implied.

The decision of the Chancery Division in Metropolitan Borough of Solibull v National Union of Teachers elaborated on the concept. ${ }^{8}$ The Borough brought a motion seeking an injunction against the defendant union which had issued 'Action Guidelines' calling on members to refuse to undertake several different requests from the Borough such as coverage for absent colleagues, coverage during lunch time, and attendance at meetings outside of school time. The union contended that although there was no ballot, the action did not constitute a breach of contract because the impugned actions were not contractual. Instead, these were voluntary actions which teachers undertook during times of labour peace. The Borough was successful in its motion with the court agreeing the items listed in the 'Action Guidelines' were not voluntary, but a contractual obligation. Mister Justice Warner found that the Borough did have authority to require teachers to fulfil these requests; even if teachers refused instructions to perform these works, they 'ought at least to give sufficient notice to enable the head teacher or the employing authority to find someone else to oversee the children at that time'.?

Building on this idea, the two ensuing paragraphs acknowledge some form of subordination of strict trade dispute tactics. More significantly, they suggest an infinite dependence on contractual interpretation. The following quotations (the first by the National Union of Teachers and the second referencing a School Board statement) dramatise the respective attitudes of the time:

As stated above, by a matter of custom and practice, the teachers' contractual hours are those of the school session (subject to the lunch-time break). There is nothing in the teachers' contract, express or implied, that entitles the plaintiffs to compel a teacher to perform any duties outside school hours, whether to attend meetings or otherwise. I refute the suggestion that a term to that effect has to be implied to give 'business efficacy' to the contract. As a matter of practice, teachers are prepared voluntarily to attend certain occasional meetings outside school sessions. It is, however, possible for meetings to be held during the school session between teacher colleagues sharing time free of pupil contact as regularly takes place. Larger staff or department meetings held outside school session hours are principally for the purpose of collective discussions of aims and objectives for the school to the professional advantage of the teachers collectively rather than as a necessary

7 ibid at [926].

8 [1985] IRLR 211 (Ch.D.) (hereinafter 'Solibull').

9 ibid at [18]. This would be consistent with legislation, for example s 234A of the Trade Union and Labour Relations (Consolidation) Act 1992, c 52. 
feature of the teaching process. Necessary communication between teachers can normally be undertaken during the sessions. ${ }^{10}$

As against that Mr. Humphrey, the plaintiffs Director of Education says in paragraph 8 of his affidavit: ' $\mathrm{I}$ am informed and verily believe that it is manifestly an implied term of each teacher's contract of employment necessary to give business efficacy to the contract that a teacher may be required to attend staff departmental or parents' consultation meetings held outside the times of the school sessions. ${ }^{11}$

Some work would be undertaken outside of the regular scope of duties on a voluntary basis for the purpose of professional advantage for the staff as a whole, although the first quotation stopped short of linking work with professionalism. ${ }^{12}$ What was clear was that teachers were willing to go beyond the work day in order to ameliorate student learning. ${ }^{13}$ In the second quotation, contractual obligation formed the sole criterion. Both parties noted the centrality of the employment contract; however, the idea of non-delineated work was treated quite differently. The Council's position relied on the 'business efficacy' argument to explain why teachers were mandated to attend meetings outside of school time.

These decisions could be explained simply as examples of the era. They arose during a time of significant labour strife in England's public sector education system. Therefore, there can be a danger to over-generalising these cases without setting them within this context. Without quibbling with that point, there may be more to the context. Through the ensuing years, specification of teachers' work obligations intensified. Concurrently, there is less discussion of increased remuneration. ${ }^{14}$ Once the Thatcher Government refused to fund the agreement (reached after much bargaining) between the teacher unions and the Local Education Authorities, the ground was set for a centralised administration of teacher pay. The government's response was the Teachers' Pay and Conditions Act 1987,15 which abolished collective bargaining arrangements and vested power with the Secretary of State to impose pay and conditions by Order: 'the legislation gives the Secretary of State virtually unrestricted powers to dictate teachers' terms and conditions. ${ }^{16}$

\footnotetext{
${ }^{10} \mathrm{n} 8$ above at [20].

11 ibid at [21]

${ }^{12}$ Although it may have been believed to be implied.

${ }^{13}$ Although for the union, there is a strong concern regarding any sort of precedent that this act may be taken to create.

${ }^{14}$ Performance pay may be brought up as a counter-point. I believe this fits better within the context of the Blair Government's management of education and more specifically the notion of partnership on which Novitz and Villiers ably elaborate: T. Novitz and C. Villiers, 'The 2006 Higher Education Pay Dispute: The Reality of Partnership Rhetoric?' (2007) 27 Legal Studies 486.

151987 c 1, repealed 6 March 1992 by the Education (Schools) Act 1992, c 38.

16 S. Fredman and G.S. Morris, The State as Employer: Labour Law in the Public Services (London: Mansell, 1989), 189 (hereinafter 'State as Employer').
} 
The 1987 response was solidified in 1988 with the Education Reform Act 1988.17 LEAs remained employers of teachers, but only nominally, for they had 'very few if any powers over the employment relationship, yet retain[ed] most of the burdens of employer'. ${ }^{18}$ This legislation embodied the government's desire to prescribe teachers' work, thereby diminishing any autonomy which teachers had previously enjoyed. One example was the unprecedented level of change the Act ushered in for English education, including a National Curriculum. The Curriculum was premised on stages of measurement ('key stages') and the identification of 'foundation subjects'. Little surprise should be expressed in the ensuing developments, which saw these measurements being published in a form which essentially ranked English schools. Far from a laissez-faire attitude, there was no question as to who had control. One author suggested that this competitive spirit was used to 'goad students, teachers and institutions as a whole to try harder'. ${ }^{19}$ The fact remained that teachers certainly were not deciding what to teach. Instead, they were left to deliver this national curriculum.

Canadian cases contained a similar line of reasoning to that found in English cases. Chief Justice Laskin's decision in Winnipeg Teachers' Association No.1 of the Manitoba Teachers' Society v Winnipeg School Division No.1 provided the starting point. ${ }^{20}$ The issue in Winnipeg Teachers focussed on whether or not teachers were required to supervise students during the lunch hour. Chief Justice Laskin found that voluntary services could, by course of conduct and of renewal of relationships over a period of time', fall under the obligations of the teachers. ${ }^{21} \mathrm{He}$ continued by defining collective agreements which arose within the 'professional enterprise':

Contract relations of the kind in existence here must surely be governed by standards of reasonableness in assessing the degree to which an employer or a supervisor may call for the performance of duties which are not expressly spelled out. They must be related to the enterprise and be seen as fair to the employee and in furtherance of the principal duties to which he is expressly committed.

...I find it entirely consistent with the duties of principals and of teachers that the latter should carry out reasonable directions of the former to provide on a rotation basis noon-hour supervision of students who stay on school premises during the noon-hour, so long as the school premises are kept open

\footnotetext{
17 c 40.

$18 \mathrm{n} 16$ above, 34.

${ }^{19}$ P. Broadfoot, 'Empowerment or Performativity': Assessment Policy in the Late Twentieth Century' in R. Phillips and J. Furlong (eds), Education, Reform and the State: Twenty-Five Years of Politics Policy and Practice (Oxford: Routledge 2001), 143.

${ }^{20}$ [1975] 59 D.L.R. (3d) 228 (S.C.C.) (hereinafter Winnipeg Teachers). Although Laskin C.J.C. wrote the dissent, his opinion regarding the relationship between the school board and the teachers was concurred in by the majority opinion of Martland J. at [243].

21 ibid at [235].
} 
at such time for the convenience of students who bring their lunches or who purchase food at a school canteen, if there be one.22

What characterised professional labour relations, according to Laskin, was reasonableness among the parties. In relation to legal argument, the test is twopart: first, the activity must have been related to the enterprise; second, the activity must have been fair to the employee.

The decision in Snow Lake School District No.2309 v M.T.S. Local 45-4 continued judicial exploration of the professional within the labour relations context. ${ }^{23}$ Again, the issue was whether or not teachers were required to supervise students during the lunch hour. The teachers had, under protest, continued to supervise lunch hour (since 1984), even though their position was that such a service was voluntary. Although the unanimous court upheld the trial decision to quash the arbitration award in favour of the teachers, Mister Justice O'Sullivan, for the court, tempered that fact as he applied the test set out in Winnipeg Teachers:

By these tests, I think it is clear that noon hour supervision is related to the enterprise of education, that it may be fair to require teachers on a rotation basis to supervise during the noon-hour provided each teacher has adequate time off for lunch, and that the supervision of children during the noon-hour is in furtherance of the duty of education to which the teacher is expressly committed.

I deplore any tendency to relegate teachers to the sole function of classroom instruction. Education is much more than merely instructing; it is a process of formation. Teachers are not simply servants of the school division; they are professional persons who function as role models and as inspirers as well as providers of information and work skills.

Drawing these threads together, public sector teachers remained employees whose duty was related to the 'professional enterprise' of education. Professional status justified the performance of non-delineated duties in the employment contract (or collective agreement as the case may be). Teachers' work did not have boundaries when forming part of the 'professional enterprise'. Though contentious, the consistency of these cases and those which followed them suggested a rather steadfast rule which stands today: ${ }^{24}$ teachers' status as employees qualifies any

\footnotetext{
22 ibid at [235]-[236]. Laskin C.J.C. also suggested that teachers should be compensated through time off for the 'inconvenience' (ibid at [236]). Much may be made of this as falling into the quid pro quo associated with Wagner Act labour relations. At that point in time, the decision could be argued that way. As time has passed, however, Winnipeg Teachers has formed the first case in a line of jurisprudence to the effect that teachers must undertake their professional duties, even if they are not explicitly outlined in their contracts.

23 [1987] M.J. No.273 (C.A.) (hereinafter 'Snow Lake').

${ }^{24}$ For example, in Ontario, Avon Maitland District School Board v E.T.F.O. [2007] L.V.I. $3744-3$ (Brent), where the Arbitrator relied on the 'test' applied where there is no express obligation on a teacher to
} 
notion of autonomy which their professional designation may suggest. Teachers have a collective obligation to 'do what it takes to get the job done'. The job is what the employer says it is (with the sole caveat being that which is unreasonable), and this is manifested through the contract of employment.

The Employment Appeals Tribunal drew as to reasonableness in Redbridge London Borough Council v. Fishman. ${ }^{25}$ Fishman had been asked to teach an additional six English classes per week. Already with a full schedule, she refused. The tribunal found that the headmaster had asked too much and found Fishman's refusal justified. The EAT, concurring, wrote:

...in our judgment, the headmaster is entitled to require teachers to do work other than that for which they have been engaged, provided that the request is reasonable. In fact this seems to have been the approach of the local authority, and when she was finally dismissed it was on the ground that she had refused to accept the reasonable instructions of the headmistress. In our judgment this is the correct approach. What is reasonable will depend on the circumstances, and no doubt will differ from time to time, and from place to place; amongst other things, bearing in mind the particular duties which the teacher was engaged to undertake. And it would be relevant to take account of the custom and practice of the profession. ${ }^{26}$

The Canadian labour arbitration case Avon Maitland District School Board v E.T.F.O. ${ }^{27}$ illustrated the principle. There were no facts to this case other than the union's general contention. Arbitrator Brent described the case as 'a situation where "standards of reasonableness" must apply to govern the extent to which the Employer can require teachers to attend divisional meetings outside of instructional time'.28 She found that the employer carries no onus to demonstrate that it is reasonably necessary for the enterprise to have divisional meetings outside the instructional day where attendance is mandatory'. ${ }^{29}$ Finding against the union, the Arbitrator relied on the bargaining history of the parties, noting in particular that the parties had not expressly prohibited the employer's ability to schedule divisional meetings. ${ }^{30}$

The English case Lake v Essex County Council ${ }^{11}$ provided further commentary on the topic, specifically that the demands of professional work would not increase remuneration beyond the contracted rate. In her unfair dismissal claim, Lake, a part-time teacher for Essex County Council, contended that she had

perform an act, found in Chief Justice Laskin's dissent in Winnipeg Teachers. Winnipeg Teachers was also relied upon in Durham Catholic District School Board and Ontario English Catholic Teachers' Association [1999] 80 L.A.C. (4th) 278 (Bendel).

25 [1978] IRLR 69 (EAT) (hereinafter Fishman').

26 ibid at [18].

27 [2007] L.V.I. 3744-3 (hereinafter 'Avon').

28 ibid at [8].

29 ibid at [9].

30 ibid at [7].

31 [1979] I.C.R. 577 (hereinafter Lake'). 
worked more than the hours for which she was paid. The Court of Appeal denied her claim (though she had been vindicated at the Employment Appeal Tribunal). Lord Denning M.R. ruled that any extra work she performed was done voluntarily and so outside of her contractual obligations. ${ }^{32} \mathrm{He}$ also contended that 'personal variation' - that is, the ability of the teacher and students as well as 'everything else that it is completely impossible to lay down any guidance for a tribunal to decide how much extra work an ordinary teacher would have to do'. ${ }^{33}$ There was no possibility of finding an implied term in the contract which would give rise to Lake's claim for damages arising from unfair dismissal.

A question continues to linger regarding the nature of the legal analysis employed. The English cases, for example, are catalogued as illustrations of the interpretation of contract terms. The inference drawn from cataloguing is that the issue is one of interpreting a professional contract of employment:

There is nothing in the teachers' contract, express or implied, that entitles the plaintiffs to compel a teacher to perform any duties outside school hours, whether to attend meetings or otherwise. I refute the suggestion that a term to that effect has to be implied to give "business efficacy" to the contract. As a matter of practice, teachers are prepared voluntarily to attend certain occasional meetings outside school sessions. It is, however, possible for meetings to be held during the school session between teacher colleagues sharing time free of pupil contact as regularly takes place. Larger staff or departmental meetings held outside school session hours are principally for the purpose of collective discussions of aims and objectives for the school to the professional advantage of the teachers collectively rather than as a necessary feature of the teaching process. Necessary communication between teachers can normally be undertaken during the sessions. ${ }^{\prime}{ }^{34}$

Mister Justice Warner looked to the conduct between the parties. It would seem that he did not in fact rely solely (if at all) on custom and practice, as he cited a number of examples of how teachers have acted, and yet, each exemplified professional activity or conduct undertaken as a means of meeting professional expectations. From this, he appeared to identify an expectation of conduct for teachers, which was couched within their professional status. It remains unclear how the interpretation of the professional contract here is distinct from implying a term of professional conduct. The normative exercise of judicial adjudication delved into the very nature of this work relationship, and the professional element was inextricable from the characterisation of the employment. The contracts were interpreted under the rubric of professional teachers. Reliance would have been squarely on the idea that professional contracts (distinct from others) cannot

\footnotetext{
32 ibid at 580 .

33 ibid.

${ }^{34} \mathrm{n} 8$ above at [20].
} 
possibly name all duties required, but that the individuals know what is expected of them.

Is it possible to argue these cross-jurisdictional cases suggest an implied term of professional expectation? The necessity of implied terms within employment contracts has been an accepted means of rectifying the incompleteness of express terms in the employment contract. ${ }^{35}$ Implied terms denote the mutuality and longevity of the employment relationship. ${ }^{36}$ The inability of the parties to specify the relationship in a precise manner prior to the initiation of contractual relations continues to be a simple fact. The force of the professional employment contract compelled (careful or begrudging, depending on your view) admission of at least an occasional need to work outside of the strict wording of the employment contract. A useful phrasing for this investigation is: a 'need to reshape employee perceptions of the "deal" they have with the organisation.'37 If the term 'professional' is interpreted in a manner which expands employees' obligations under the contract, can we say that a term has been implied into the contract? It would appear so. We may even contend that these cases have restated the work of teachers: 'the implied terms which result from inquiries may become so fundamental as to amount to general norms for a wide range of personal or employment contracts, or even for the totality of personal work or employment contracts. ${ }^{38}$

It is worth addressing proximity in the term 'professional enterprise' to 'business efficacy'. What underlay the decisions was the notion of necessity: teachers must do this because it was necessary to the proper work of schools. Necessity seemed to be a key element of what was meant in either phrase. The other element was the work carried out by teachers as professionals. Thus, was it necessary for the professional work of teachers to imply a term into the contract of employment? Arguably, what the courts had done was to imply such a term, but to call it an interpretation of the employment contract. Unfortunately, it remains unclear whether or not this was an instance of implied terms or an interpretation of a professional employment contract.

Putting aside the debate as to characterisation, it has been clear that professional status has been linked to expectations. Borrowing from the emphasis placed by the Canadian Supreme Court on the professional enterprise, 'professional expectations' satisfies the demanded standard because the essence of these cases is imperative: professionals will/must do whatever it takes (within the limitations of reasonableness) to successfully support the professional enterprise. To fulfil professional expectations requires teachers to act in a manner which is construed as consistent with their status; the power of interpreting the meeting of this threshold rests with the employer. It would appear that there will be

\footnotetext{
35 S. Deakin and G.S. Morris, Labour Law (Oxford: Hart Publishing, 5th ed, 2009), 4.6.

36 ibid.

${ }^{37}$ D. Marsden, 'Individual Employee Voice: Renegotiation and Performance Management in Public Services' (Centre for Economic Performance Discussion Paper No. 752, October 2006), 3. $38 \mathrm{ibid}$.
} 
deferential treatment to the employer's decision, given that each instance vindicates the employers' position. What constitutes a professional expectation has been interpreted as that which employers assert their employees must do within reasonableness (a threshold which seems to offer professional employees little protection). For example, teachers must attend meetings after school hours because it permits business efficacy. ${ }^{39}$ As a result, the employer has flexibility within the contract of employment so that if the need arises, it can compel employees to perform work not specifically contracted. For two reasons, it is unlikely that this concept of the teacher professional will be undermined. First, there is a relatively lengthy history of this interpretation. The dates of the jurisprudence are also suggestive. Before talk of flexicurity arose, these cases were reinforcing an expanded expectation of professional employees. Second, even the public sector services must be able to compete in the global market place. ${ }^{40}$

The flexibility evident in teachers' contracts alluded to a distinct change. Unlike the idea of flexicurity, job security has been distinctly absent. There was a time when a public sector job equated to job security. Not simply a fact of change in the public sector, its significance is now greater. This is a measure of how far the government has departed from being a model employer. Government in both England and Canada once led the way for unionisation (a prime factor in explaining why unionisation is currently highest in the public sector). Today, government operates more like a private company than its predecessors.

As matters have tended to do so in employment law discourse, it may be wondered whether these cases suggested an extension of subordination?41 Utilisation of professional status as a means for expanding what work was expected of individual employees suggested a diminishing of what skills teachers brought to their work. It was not insignificant that while there was talk of flexicurity, greater specification of work duties for teachers also arose (we may broaden this to include public sector employees whose work can be classified as professional). Flexibility has always been highly desirable for public sector employment contracts. Even where the employment contract did not provide for an express term (or even one upon which the court could rely), the notion of the professional endeavour was utilised to explain why teachers have an obligation to perform unspecified duties. The combination disclosed how public sector teachers worked within an environment which had a tradition of accommodation. The premium placed on permitting a full range of choices for management has long been present. It may be added that this fits generally within the context of employment law. Taking dismissal as one example, employers are found to have

\footnotetext{
39 'Professional enterprise' hints at this (if it is not explicit). Still, business efficacy renders the point more directly.

${ }^{40}$ Novitz and Villiers draw this link in the example of higher education (n 14 above, 588).

${ }^{41}$ M. D'Antona, 'Labour Law at the Century's End: An Identity Crisis?' in J. Conaghan, R.M. Fischl and K. Klare (eds), Labour Law in Era of Globalization (Oxford: Oxford University Press, 2002).
} 
transgressed the boundaries of reasonableness only in the 'extreme cases involving arbitrary, unreasonable and capricious treatment.' 42

A leading purpose of flexibility ${ }^{43}$ has been 'to improve the competitiveness of business so that they may survive and prosper in an increasingly global economic system.' 44 As teachers' contracts have long contained this flexibility, the question arises of whether or not flexibility and subordination had overlapped when discussing the work of teachers. One may point to campaigns by public sector unions (for example, the National Union of Teachers' current campaign for pay increases), which will call for a pay rise because salaries have fallen well behind the commonly-used 'floor' of inflation. These campaigns suggest either a willingness by these unions to allow for a lower-than-market-value increase in pay (perhaps as a trade-off for another item of importance to membership) or a lack of opportunity to prevent this occurrence. Clearly, the public's parsimonious attitude towards public sector pay rises now has found an equally miserly partner in the political parties in government. Consequently, public sector teachers (as one example) are subordinate; indeed they subsidise the services they provide and remain consistently aware of the 'professional expectations' of their work.

\section{CONTRACT AS MEDIUM}

The pre-eminence of the contract as the instrument delineating teachers' relationship with employers fits within a larger framework of contract as the medium for outlining relationships of varying kinds. Contract has been noted for its universality because it has formed the mechanism through which negotiation and business (including employment) dealings are conducted.45 This idea of contract as a 'self-contained and universal form beyond the reach of any legal relationship'46 contains a novel duality. It is both trite and obvious to note and yet remains profound, ${ }^{47}$ especially in the public sector labour law context. The contract is a regulatory tool for government and as such forms a means of controlling the work relationship.

Once the parties reach an agreement, its terms must be respected. Jurisprudence in both jurisdictions has suggested that when an employer utilised an argument tied with teachers' professional responsibilities, the employer was

\footnotetext{
42 S. Anderman, 'Termination of Employment: Whose Property Rights?' in C. Barnard, S. Deakin and G.S. Morris (eds), The Future of Labour Law: Liber Amoricum Bob Hepple Q.C. (Oxford: Hart, 2004), 109.

${ }^{43}$ Flexibility has been noted as 'a new theme [which] has emerged as the dominant strand in government polices with respect to labour law' (H. Collins, 'Regulating the Employment Relation for Competitiveness' (2001) 30 Industrial Law Journal 17, 18). As the pace of change moves quickly, so too does its language. In 2007, the Commission for European Communities released a report, 'Towards Common Principles of Flexicurity: More and Better Jobs Through Flexibility and Security', which elaborated on the term 'flexicurity'. This term was defined as 'an integrated strategy to enhance, at the same time, flexibility and security in the labour market' (5).

44 ibid.

45 A. Supiot, 'The Dogmatic Foundation of the Market' (2000) 29 Industrial Law Journal 321, 325.

46 ibid, 328.

47 '....in labour law the contract has been given precedence over law' (ibid, 329).
} 
more likely to succeed. A union grievance regarding a matter which occurred during the term of an agreement pertaining to a professional-type issue (though issues would not be limited to this form) was less likely to be resolved in teachers' favour and so redress would come at the expiration of the contract during the ensuing negotiations. In each of England and Ontario, teacher unions have resorted to very public campaigns in order to address grievances. This option arose after lengthy periods of negotiation, which presented varying degrees of success in England up to the early 1980s, but rather significant upward progressions for Ontario teachers up to the mid-1990s. The noteworthy shift in strategy suggested a reconceptualising of the relationship. While the contractual paradigm remained, teacher unions sought superior means of creating leverage in negotiations for the purpose of yielding a more favourable agreement.

The strategy constitutes an indictment of the existing framework (at least from the employees' view). ${ }^{48}$ Of particular interest, teachers unions' strategies, though, both challenge and acknowledge the pre-eminence of the contract. One may suggest that in order to address the lopsided nature of public sector negotiations (where employees subsidise the system to a certain extent), public campaigns have been initiated so that the public better understands teachers' position as service delivery professionals. Thus, the campaign seeks to counteract the imbalance. By using the campaign, there is an acknowledgement of the imbalance.

There is a danger in being unnecessarily normative; however, there is material, which, normative or otherwise, contributes to the ongoing development of public sector labour relations. There is a limitation to how far self-contained negotiation can take each party's interests before either one considers the parameters to be restrictive. By taking the argument to the people (in a manner), it may be contended that the process of public sector labour relations bargaining becomes more representative; public support will champion one side over the other. It has been a delicate balance, which has presented its own challenges: although this democratic argument was simplistic yet plausible, it presumed that the public would weigh the options carefully. Contributions to this area and to politics more generally suggest that self-interest often tips the balance. Put crudely, if it would cost the taxpayers more, the likelihood would be that a majority of the public will reject those arguments which raise expenditure and therefore taxes. Ostensibly, this leaves us relatively where Summers had long ago identified: a position in which teachers unions remain vulnerable to the public's aversion to taxes. It may be somewhat unsettling to more significantly rely on the quicksand of public opinion. These campaigns have been waged by each side for the purpose of

\footnotetext{
48 This question is one of many currently posed of employment law. For example, Mark Freedland has queried personal employment contracts: 'Once we recognise that the whole world of contracting for personal work relations does not have to be centred upon or constructed entirely around the single model of the contract of employment, a more subtle and functional set of analyses becomes available, not only of the whole range of personal work contracts as I have argued down to this point, but also of these arrangements or contracts which are associated with or incidental to personal work relationships, though not themselves amounting to personal work contracts' (n 2 above, 25).
} 
expressing overarching principles, thereby implying that the other side is deficient in comparison. In attempting to create leverage at the bargaining table, teachers unions have put themselves more centrally in the minds of the public.

The alteration to the welfare state constitutes a further dimension to the centrality of contract in public sector labour law. No question the welfare state has been weakened and that the globalised market place has played a significant role in that decline, ${ }^{49}$ with the result that the contract has become the receptacle of responsibilities. Government continues to increasingly rely on contract as a regulatory tool to expand obligations, while controlling pay rises. In so doing, government has committed to demonstrating its ability to manage itself as an efficient business - as assessed by the 'proper' administration of its portfolios. Management of education, having been relied upon as the pivotal means for empowering citizens to achieve, is one of these measures. Discussions in England have been initiated regarding formalising the expectations of teachers within the employment contract as opposed to leaving it to contractual interpretation or implied terms.

The British Secretary of State has recently called for restatement of teachers' employment contracts so that teachers' professional responsibilities are explicit. The 2008 report of the School Teachers' Pay Review Body (STPRB) considered this proposal as the Secretary sought its direction regarding such a restatement..$^{50}$ The STPRB reiterated some 'shortcomings' it had identified in the current statement of teachers' professional responsibilities. The Body decided on a separation between any future restatement (for the STPRB found this not to be an opportune occasion for restatement $)^{51}$ and the employment contract:

We continue to support separate presentation in this way. We are not persuaded that the substance of statements of responsibilities and of conditions of employment is intrinsically linked. It is not clear that changing statements of teachers' responsibilities would necessarily have a bearing on the conditions of employment in the STPCD, or vice versa. It is not, therefore, necessary for work on teachers' responsibilities to be done as part of or in parallel with work on conditions, or for changes to the STPCD to be made as a single package. 52

The STPRB's perspective constituted sound reasoning, but still, there appears to be will at the current government level to connect a professional statement of teachers' responsibilities as an addendum to any employment contract. Such a connection warrants careful consideration because it can disturb the cosy flexibility which the current jurisprudence gives to the education employer. The

\footnotetext{
${ }^{49}$ Supiot, n 45 above, 337.

50 School Teachers' Review Body 17th Report, Part 2, 2008 CM 7352 (hereinafter 'STPRB').

51 'Our Sixteenth Report recommended that new statements of responsibilities be in a dedicated section of the STPCD, separate from conditions of employment' (ibid, 13)

52 ibid, 13.
} 
effect of greater prescription of responsibilities and endeavouring to render them explicit contractual obligations presents an opportunity for teachers. With greater specificity in the employment contract (again, the contract coupled with any restatement of professional undertakings), the more likely it is that the provisions may be read against the employer. The intrigue in the movement traced above is its contrapuntal nature: while there has been increased contractualisation, the trend does not signal 'that the proportion of prescribed bonds within society is declining in favour of agreed bonds' in the public sector. ${ }^{53}$ Despite the reluctance of the STPRB, the call for greater specificity casually alludes to the influence (and notion) of the public interest which underlies such a discussion. ${ }^{54}$ The contractual expectations of teachers are cast broadly within the concept of public policy found in the law of obligations: that which is not favourable to the state contravenes public policy.

\section{CONFIRMING AN ADVANTAGE}

With the above elaboration of a 'professional expectation' within teachers' employment contracts, what was seen as a partnership is more appropriately described as employer's advantage. ${ }^{55}$ In this section, two examples are referenced: in England, an outcome of a 2004 agreement between Labour and the teachers' unions; in Ontario, the government policy towards use of non-unionized Early Childhood Education trained personnel in the first two years of schooling. The comparison will highlight the predicament in which teachers' unions now find themselves.

In its report Reforming and Developing the School Workforce, ${ }^{56}$ the Office for Standards in Education, Children's Services and Skills (OFSTED) noted improvement in the amount of time teachers have to devote to their students combined with a need for systems to evaluate progress and summarized the content of this report for the age group 3-19. OFSTED outlined the progress which it perceived has occurred through the significant changes to the education sector in England over the past decade. The content of the OFSTED report will be outlined with a focus on identifying the underlying emphasis contained therein and then followed by a contrast with recent events in Ontario.

Reforming and Developing stemmed from an initiative dating back to January 2003, when the Government, employers, and teacher unions (except the largest

\footnotetext{
53 Supiot, $\mathrm{n} 45$ above, 326.

54 The Honourable Justice Susan Kiefel provides an intriguing and brief canvass of the role of public policy in the law of obligations: 'The Role of Policy in the Law of Obligations' in C.E.F. Rickett (ed), Justifying Private Law Remedies (Oxford: Hart, 2008).

55 D. Guest and R. Peccei, 'Partnership at Work: Mutuality and Balance of Advantage' (2001) 29 British Journal of Industrial Relations 207.

56 Office for Standards in Education, Children's Services and Skills, Reforming and Developing the School Workforce (London: OFSTED, 2007) (hereinafter Reforming and developing).
} 
organization, the National Union of Teachers $)^{57}$ agreed to the principles contained in Raising Standards and Tackling Workload: A National Agreement.58 The dual focus of this agreement was the reduction of teacher workloads leading to improved standards for students. Reforming and Developing is the latest in a series of such documents (dating back to December 2004) which evaluated the implementation of that agreement.

The agreement reached between teachers unions and the government also brought to light how employees may be acolytes of a reform agenda. A provocative focus for discussion, a simple agreement between labour and management did not necessitate this scenario. Consider the following statement from OFSTED: 'Workforce reform encourages schools to deploy a wider workforce with diverse expertise and skills to embed the Every Child Matters agenda more fully. ${ }^{59}$ The latter part of this sentence prompts serious consideration. Are teachers embedding a government agenda? When considered in the context of the union/government agreement, the implication raised troubling points. Did a teachers union subscribe to a government's agenda if it signed a workplace agreement? Was this an example of a union seeking to buoy a 'Labour' government after years of unfriendly Conservative governance?

The situation in Ontario may appear to fall into the latter situation. Leading up to the (Fall) 2007 provincial election it was reported that the Liberal Government (which had won the 2003 election and was seeking re-election which the Liberals subsequently won) would put $\$ 400$ million into a full day 'daycare' program. Noting the distinct language used, the reporters wrote, In effect, it's full-day kindergarten, but the Liberals, mindful of the concerns of teachers' unions, have dubbed it "a full-day pre-school program"...If it were considered full-day kindergarten, only teachers could provide instruction, insiders say. ${ }^{60}$ The proposed plan could be considered a re-categorization of teachers' work. There had been no response from the unions (particularly those dealing with elementary school teachers) during the election. Absence of response implied that the present Government was one that the unions wanted to remain in power, so they were loathe to undermine its position as government at such a critical juncture. In this instance, the unions have engaged in supporting the party which would be (in their estimation) the best bargaining partner. What effect does such strategic support have on teachers unions? In an election year, teachers are likely not to raise a fuss which would hurt support for their favoured political party. When an election was not imminent, however, the timing was far superior. As

\footnotetext{
${ }^{57}$ One of the most significant points of opposition for the N.U.T. was the fact that 'major issues [were] yet to be resolved' (National Union of Teachers, 'Advice Concerning the "Agreement" Headway for the Leadership Group' (February 2003), 2 (hereinafter "NUT Advice”). Nevertheless, the Agreement did impact N.U.T. members since it resulted in changes to the School Teachers' Pay and Conditions Document and related legislation.

58 (15 January 2003) at: www.tda.gov.uk/upload/resources/na_standards_workload.pdf [Raising standards]. 59 Office for Standards in Education, Children's Services and Skills, n 56 above, 12.

60 L. Monsebraaten and R. Benzie, 'Liberals Woo Parents' (6 September 2007) at http://www.thestar.com/Ontario\%20Election/article/253727.
} 
outlined below, recent comments revealed noted opposition to employment of educators with credentials other than those teachers have.

In 2009, the true feelings of teachers unions towards the 2007 proposal became clear. There had been a concerted effort in 2007 to avert the appearance of negativity for a government that had been otherwise friendly to their members. We found the evidence of this in the reaction to the recent report on early learning in schools. ${ }^{61}$ The Pascal Report called for individuals trained in Early Childhood Education (ECE) to be employed in kindergarten (teaching children aged 4 and 5) and that this teaching be modified from a half-day curriculum to a full-day program. Unions swiftly responded, but not all registered their disagreement as to staffing this amended program. Opposition was limited to those unions whose members included elementary school teachers, ${ }^{62}$ while the only union which represented secondary school teachers (and non-teaching personnel) was in favour of the Pascal Report.63 The Elementary Teachers' Federation of Ontario (ETFO) took a more aggressive line in its press release, which is summarised by the following excerpt: 'ETFO rejects Dr. Pascal's notion of replacing qualified teachers in Kindergarten programs with staff with lower credentials...64 ETFO linked quality education with teacher training and inferred that ECE trained educators diminished young children's opportunities for personal development. ${ }^{65}$

What do we gain from dissecting these examples? Labour issues are wedded with education reform initiatives. This is both commonplace and innovative. Traditional rhetoric blaming unionized teachers for poor standards is premised on the link's obviousness. However, the idea of an agreement with teacher unions as a means of facilitating improvement is distinct simply because reform efforts continue to be full of labour relations implications. Still, with these explicit agreements or perhaps tacit endorsements, there was a greater shared stake in the enterprise when both sides agreed to standards for improvement. In one sense, it

${ }^{61}$ C.E. Pascal, With Our Best Future in Mind: Implementing Early Learning in Ontario: Report to the Premier by the Special Advisor on Early Learning (Ontario: Queen's Printer for Ontario, 2009) (hereinafter Pascal Report').

${ }^{62}$ Both the Elementary Teachers' Federation of Ontario (ETFO) and the Ontario English Catholic Teachers' Association (OECTA) suggested the report fell short of ideal recommendations and focussed their criticism on the staffing issue. OECTA for example, released a statement which included the following: "It is also clear that certified teachers, more so than paraprofessionals, can provide both learning and care. Teachers can balance learning through play and readying children for formal education. And finally, the research shows that when programs are adequately funded children succeed," Mac Neil says. OECTA has presented this position in its brief and in face-to-face meetings with Dr. Pascal.' (OECTA, 'Teachers Should Deliver Full-Day Learning Program to 4- and 5-Year Olds' (15 June 2009) at http://www.oecta.on.ca/news/nr2009/nr_fulldaylearning_June09.htm.

${ }^{63}$ The Ontario Secondary School Teachers' Federation (OSSTF) 'applauded' the government: OSSTF, 'New Early Years Plan Strengthens Ontario Education' (15 June 2009) at http://www.osstf.on.ca/Default.aspx?DN=1d5825fe-6755-4336-88bb-1e23a59a4dac.

64 Elementary Teachers Federation of Ontario, 'Full-Day Kindergarten Best Delivered by Certified Teachers' (15 June 2009) at http://www.etfo.ca/MediaRoom/MediaReleases/Pages/FullDay $\% 20$ Kindergarten $\% 20$ Best $\% 20$ Delivered $\% 20$ by $\% 20$ Certified $\% 20$ Teachers.aspx.

65 If Ontario truly wishes to be a leader in ensuring that all our children get the best possible start in life, our children must begin their journey in the best possible learning environment. That environment is one in which certified teachers occupy the critical role' (ibid). 
diminished the blame which one side might have laid on the other for a proposal's lack of success.

There are two general themes inherent. First, we can identify the implications of monopsony. ${ }^{66}$ Public sector education contains one buyer, yet many sellers of teaching services. These services also come in different forms - from the qualified head teacher to the unqualified volunteer. The buyer (government) may have been bolder in its actions than it may have been where it was competing with other buyers for teachers' services. Second, and a point related to the first, witness the limitations of collective negotiation/pay arrangements where there was an exchange of labour peace for a contract. Once an agreement was reached with teachers unions, the government was insulated from industrial action; that is, unions were required to take gradual steps before members may could be mobilized in protest. Within this leeway, the government could operate in a rather liberal manner. Where were unions in this? Novitz and Villiers' proposition stands as an accurate rendition of what has arisen in public sector employment:

...the public sector has also been marketised to an extent sufficient to require a similar approach at an enterprise level to prove sector partnerships. Such an interpretation would impose a restriction on union's opportunities to pursue broader projects or even the employment security and welfare aspects of the partnership. ${ }^{67}$

Teacher unions currently face a significant quandary. If they support or prefer a certain political party to remain be in power, they may also be leveraging themselves into a vulnerable position. Overtly supporting a political party may also have its detrimental results.

\section{SCOPE FOR THE EMPLOYER IN A 'PROFESSIONAL ENTERPRISE'}

It seems trite to write how important schooling is to society as a whole. And yet, this has been how professionalism as a term interpreted or implied in the employment contract continues to be constrained. For all the wrangling over what duties teachers should have and for which they should be further remunerated, there remains a tangible effect on the students. In discussing the effect, we also recognised degree. The public has countenanced some level of disruption to the school year. A one-day strike, for example, will be considered more of an inconvenience, but attitudes change with each further day of strike.

\footnotetext{
${ }^{66}$ Simply put, 'monopsony' means a situation in which there is one buyer in a labour market (V. Bhaskar, A. Manning and T. To, 'Oligopsony and Monopsonistic Competition in Labor Markets' (2002) 16 Journal of Economic Perspectives 155, 156).

${ }^{67}$ Novitz and Villiers, n 14 above, 488.
} 
Latitude has been built into this idea of the professional enterprise which functions disproportionately as the interpreted or implied term of professionalism tends to favour the employer. There has been little to suggest that this would be considered inappropriate by a majority of the public. Lay opinion appears to have come to the conclusion that, to put it rather coarsely, the education of children is too important to leave up to individual teachers. Certainly, there has been distrust of what teachers may do without government pressing upon them an itemisation of what they must do. Such distrust is consistent with an overall shift crystallised in England with Labour coming to power in 1997, when '[n]o major political party was...seeking to convince the electorate that peaceful industrial action should be unregulated or even that the particular controls put in place by the previous Conservative administrations should be substantially amended'.68 The current Ontario Government has taken steps towards a similar result. Dialogue had been initiated by the government amongst the parties in 2008, but in a more directed manner, as the government was not simply facilitating discussion. While less confrontational, the move retained a firm grip on bringing about a palatable result. Throughout the year, the government, school boards, and teachers unions entered into negotiations to establish a framework agreement. Among the highlights of the arrangement was a steady increase in remuneration to a top rate of approximately $\$ 95,000$ (CAD) and the requirement that teachers be in their classrooms fifteen minutes prior to the start of classes. This latter aspect formed an obvious response to the labour grievances (launched primarily by elementary teachers in recent years) which have contested when teachers' work days begin. All the teachers' unions have signed on to this agreement. ${ }^{69}$

What this meant for the concept of the professional enterprise was that government, as (at least virtual) employer, could press on with forcing more duties upon teachers. In order to limit this expanding body of obligations, teachers have few options - the strongest of which is to demonstrate how an abundance of forced duties negatively affects the professional enterprise; that is, too much work will diminish the individual return for each student as teachers will not have time to devote to a student's individual needs. It remains to be seen whether this framework may be modified in a manner that mitigates the rather prevalent unilateral imposition of duties. One factor in the success of such a move would be teachers unions' willingness to play a greater role in decision-making, thereby exposing themselves to greater responsibility for the state of affairs in education. If the consistent argument of teachers unions has centred on involvement in decision-making, it would seem evident that the unions must also accept the accompanying responsibilities of this desired level of involvement. In order to facilitate this, government (and local education authorities) must accept this model

\footnotetext{
${ }^{68}$ P. Davies and M. Freedland, Towards a Flexible Labour Market: Labour Legislation and Regulation since the 1990s (Oxford, OUP, 2007), 111.

${ }^{69}$ The elementary teachers refused to sign prior to the expiration date of the original offer. As a result, their members worked under a deal which finished sooner and offered a lower pay rise than their provincial colleagues.
} 
which treads into the partnership realm. Thus far, there has been no indication that a decision-sharing model will be enacted. And yet, it would appear as though professional teachers are well-situated for such a change. There would be room to better manoeuvre around the confines of the employment contract by returning to the autonomy of professionals. This would not be a return to the mid-1970s model which was so heavily criticised. Rather, stepping back from contractualising every aspect of teachers' work would permit the notion of professionalism to develop more organically. Indeed, this may be a superior means of engendering what government seeks because unilateral imposition has not had the most impressive history of success.

\section{CONCLUSION}

Returning to the phrase coined by Laskin C.J., both parties have a mutual obligation to the 'professional enterprise,' but its operation has to date only affected teachers - whether it is called an implied term or an interpretation of the contract. The link between the employment contract and the obligation to work towards the professional enterprise relies on teachers' status as employed professionals.

The current trend in England is most intriguing as there is growing fervour to explicitly state teachers' professional duties in some form which would then be attached to the employment contract. The danger here is that the leeway historically enjoyed by government/education authorities can be undermined: if the terms of the professional enterprise (pertaining to teachers) are enumerated there is less room for debate regarding areas not specifically mentioned. Jurisprudence has previously worked in favour of education employers in this regard, and it is asserted that the presumed lack of capacity to specify the contents of professional teachers' employment contracts played a larger role in the decision. If this presumption is undercut (if not removed), so too is the flexibility previously found.

Ontario has also pushed for more, but the manner has been different. Instead of unilateral imposition, the Ontario government, since 2005, has brought the parties together to agree to a detailed framework which essentially forms the collective agreement applied throughout the province. Since all parties are involved in the formation of the contract, it is harder for the teachers' unions to make a similar argument as above. The difficulty there (and one to which English teachers are not immune) is whether this will place the teachers' unions in a corner: will they too be linked with the one political party and therefore vulnerable (again) to Conservative reforms?

Given these looming challenges, it would appear that another means of engaging the teaching profession would be advantageous - one which utilises the employment contract as a mode of parameter-setting, but not the end itself. As 
well, teachers unions must take care that they do not confine themselves to a political party and a particular model of governing interaction with government. All told, the present presents a good occasion for those involved to investigate new ways of meeting contemporary challenges. 